[American Journal of Science, Vol. 303, November, 2003, P. 856-864]

\title{
THE PLACE AND POWER OF MYTH IN GEOSCIENGE: AN ASSOCIATE EDITOR'S PERSPECTIVE
}

\author{
WILLIAM R. DICKINSON \\ Department of Geosciences, University of Arizona, Tucson, Arizona 85721; \\ wrdickin@dakotacom.net
}

\begin{abstract}
Distinguishing between myth and science is subtle, for both seek to understand the things around us. The characteristic style of mythic thinking is to place special emphasis on a selective conjecture, based typically on the initial observation or recognition of a phenomenon, which is thereafter given privileged status over alternate interpretations. Concepts in geoscience are quite commonly mythic in that sense. The outdated notion of geosynclines as deterministic precursors of orogeny is an apt example, as are central current ideas about suspect terranes, mantle plumes, and global sequence stratigraphy. Geomyths stimulate investigation, but also may retard further progress by dismissing contrary views. Improved understanding of geologic history could be attained more efficaciously by appreciating the mythic quality of many nascent ideas in geoscience, and resisting the temptation to accord geomyths favored status over competing hypotheses.
\end{abstract}

\section{INTRODUCTION}

In our discourses, we commonly counterpose myth, taken to be imaginary, and science, conceived as an approach to reality. Both myth and science, however, strive to explain the same features of the natural world. Distinguishing between the two is difficult, posing a challenge that accounts for the persistence of pseudoscience in popular culture.

In the days when a god supposedly drove a chariot of fire across the heavens to make the sun shine, that explication of night and day seemed no more mysterious to most people than life itself. It is not easy even now to define myth separately from science. Each attempts a comprehensive view of our surroundings, and each provides an explanation for some salient package of observations giving rise to quandary. It is perhaps the defining style of mythic thinking to build selectively upon some particular conjecture that is given privileged status against contradictory observations. Rejecting any myth typically requires more conclusive evidence than its initial invention employed.

\section{BACKGROUND}

I contend that geomyths have played a role in the evolution of our science, and are still with us today. A preordained geotectonic cycle, derived conceptually from the durable myth of geosynclines, held center stage only a few decades ago until plate tectonics showed a better way to reconcile observation with concept. At present, tectonics has its suspect terranes, petrology its mantle plumes, and stratigraphy its global sequences. Each of these concepts is a myth in the sense that each expands selectively from a narrowly focused appraisal of an issue to embrace far-ranging analysis, and each places an extra onus of argumentation upon potential detractors.

The logic of any geomyth rests upon an inductive leap extrapolated from some particular observation or assumption inferred to lie at the root of an issue being addressed, and rejects the spirit of the familiar method of multiple working hypotheses (Chamberlin, 1897). The style of myth instead posits dominance of a single perception to the exclusion of others. This approach makes geomyths difficult to falsify, yet most agree (with Gilbert, 1886) that essential tests of scientific ideas must embody attempted disproof, rather than a search for confirmation (Popper, 1962). 
Geomyths tend to be more durable but also less specific than leading or ruling hypotheses. Hypotheses are abandoned, or changed in substantial ways, if their predictions fail. When predictions of the extant version of a geomyth fail, however, the characteristic response is to change underlying assumptions, or evaluations of constraints, in ways that keep the core of the geomyth essentially intact.

My examples of geomyths are drawn from my own personal research experiences, and those with different interests and expertise could doubtless highlight others. Applying the term myth to an idea is not meant to be pejorative, but to describe the manner of its origin and retention.

\section{GEOSYNCLINAL THEORY}

The idea that geosynclines predestine orogeny was built on the valid observation that folded sedimentary strata of the valley-and-ridge province of the Appalachian chain are thicker than flat-lying strata of equivalent age beneath the Appalachian Plateau to the west (Knopf, 1948). As ultimately developed, the logic linking subsidence and thick geosynclinal sedimentation to later mountain-building along the same linear trend gave rise to the concept of a fixed geotectonic cycle (Cady, 1950), holding that the inherent nature of geosynclines leads inexorably to paroxysmal orogeny. Diverse views of the impulses for geosynclinal subsidence and the nature of geosynclinal sedimentation emerged over the decades, but the presumed genetic linkage between geosynclines and orogeny persisted despite shifting viewpoints (Hsü, 1973).

The notion survived the observations that some mountain belts lack excessively thick strata, and that some thick piles of sediment seem never to have fostered orogeny. These aberrant observations, in apparent conflict with theory, were treated conceptually by supposing that some otherwise satisfactory geosynclines were simply starved for sediment, and that some thick prisms of sediment are not "true" geosynclines. The latter were termed orthogeosynclines, composed of parallel eugeosynclinal and miogeosynclinal belts, to distinguish them from comparably thick sedimentary accumulations that fail to foreordain orogeny (Kay, 1951).

Caught up myself in the seductive geosynclinal web of logic, I once argued on the basis of andesite geochemistry (Dickinson, 1962) that eugeosynclinal crust similar to the modern crustal profile has been present since mid-Paleozoic time beneath western parts of the North American Cordillera in ground we now infer to have been accreted from ocean to continent almost entirely after mid-Paleozoic time. My arguments were largely circular, however, and appreciating the mechanisms of plate tectonics soon showed that eruptions of andesite are related to plate descent along subduction zones (Dickinson, 1970), rather than to any supposedly eugeosynclinal environment of crustal magmatism.

The advent of plate tectonics made the geosynclinal myth unnecessary. Various kinds of "geosynclines", ortho- or not, were seen by actualistic analogy as different types of sedimentary basins in different plate settings (Mitchell and Reading, 1969; Dewey and Bird, 1970; Dickinson, 1971a). No one bothered with formal refutation of the geosynclinal theory of orogenesis, but most moved at once to other models for orogeny as a function of plate interactions (Dewey and Horsfield, 1970; Dickinson, 1971b). Geoscientists are still engaged collectively in modifying and improving the plate models. Geosynclines are precursors of mountain belts only if we define the stratified rocks of mountains as geosynclinal deposits, but this is tautology without fundamental meaning (Hsü, 1982).

Coney (1970) picturesquely discarded the traditional geotectonic cycle: "saying geosynclines lead to orogeny is a little like saying fenders lead to automobile accidents". He had in mind, of course, the deformation that crumples and dislocates thick sedimentary accumulations deposited along continental margins when an intervening ocean basin is closed by plate consumption. Having no further need for the mythology 
of geosynclines, we essentially dropped the word from our geovocabulary, saving only the derivative term miogeocline (Dietz and Holden, 1966) for sediment prisms deposited along passive continental margins.

\section{SUSPECT TERRANES}

Terrane analysis was devised as an antidote for overly facile plate interpretations of orogenic belts, with the North American Cordillera as exemplar (Coney and others, 1980). The aim was to define objectively a finite number of fault-bounded components of an orogen as strictly descriptive entities, each with its own consistent internal stratigraphy (including basement where exposed) not demonstrably contiguous with the stratigraphy of adjacent terranes. Named terranes bear a hierarchic relationship to orogenic systems as a whole similar to the relationship, in American stratigraphy, of formally named formational units to overall depositional systems. Each tectonostratigraphic (or lithotectonic) terrane is treated as a separate entity because it displays a degree of internal continuity that is interrupted at terrane boundaries more abruptly than facies change can readily explain (Keppie and Dallmeyer, 1991).

Orogenic terranes displaying stratigraphy that contrasts with the cratonal stratigraphy of a continental interior (Laurentia in the North American case) are designated "suspect" terranes, meaning that they might have been accreted to the continental block by tectonic transport which occurred after some or all the rock masses within each suspect terrane were formed. Explicit recognition of suspect terranes can be helpful in dissecting the accretionary anatomy of orogenic belts (Williams and Hatcher, 1982; Monger, 1993), although a widespread tendency to regard all terranes designated suspect as necessarily exotic to the adjacent craton is a questionable approach (Hudson, 1987).

For evaluating potential movements of suspect terranes, heavy emphasis is placed in practice on remanent magnetizations preserved by rock masses within suspect terranes as apparent recorders of paleolatitude (Irving, 1979; Irving and Wynne, 1990; Beck, 1992; Irving and others, 1996). This emphasis derives from the perspective that paleomagnetism is a more objective criterion than geologic interpretations, which may be faulty (Coney, 1989). Discordances between paleomagnetic vectors recorded by suspect terranes and the vectors expected from their present positions with respect to adjacent cratons are accordingly taken as presumptive evidence for tectonic transport of the suspect terranes relative to the cratons.

Arguments that some paleomagnetic discordances within deformed orogenic belts can be interpreted instead as the results of pluton tilt, sediment compaction, or acquisition of remanence during the folding of tilted strata call this presumption into question (Butler and others, 1991, 2001, 2002). Preferential reliance on the paleomagnetic signature of deformed rocks as a faithful record of paleolatitude has the hallmark of mythic thinking, and seems unnecessarily restrictive. Evaluation of terrane motions can be made with confidence only by adopting a multidisciplinary strategy (Cowan, 1994; Cowan and others, 1997; Mahoney and others, 2000). In its absence, conflicts between paleomagnetic and other geologic evidence for and against postulated terrane displacements (Irving and others, 1985 vs. Vandall, 1993; Gastil, 1991 vs. Beck, 1991; Monger and Price, 1996 vs. Wynne and others, 1996) seem likely to persist unresolved.

There is no inherent contradiction between terrane analysis and plate tectonics, for the history of any terrane can be interpreted in the context of plate models (Dickinson and Lawton, 2001). Terrane analysis proceeds initially, however, without regard to specific plate models, from the perspective that terrane amalgamation results from obscure plate interactions that are too uncertain to provide a reliable guide to terrane relationships (Howell and others, 1985). In this context, the differentiation of discrete terranes can be viewed as a goal unto itself. Without close attention to the 
varying tectonic nature of terrane boundaries (Ernst, 1984; Şengör 1990; Şengör and Dewey, 1990; Hamilton, 1990), terrane nomenclature can proliferate (Karl and Mull, 1993) without elucidating generic tectonic relationships. Allegiance to the original spirit of terrane analysis requires striving beyond simple delineation of terranes, and documentation of their paleomagnetic signatures, to perceive the plate interactions that produced their internal character and placed them in close juxtaposition.

MANTLE PLUMES

Once it was understood that plate tectonics is the "way the world works" (Wyllie, 1976), it became clear that most volcanism on Earth occurs either along midocean ridges and other rifts at divergent plate boundaries, or along magmatic arcs where eruptions are triggered by plate descent at convergent plate boundaries (Martin and Piwinskii, 1972). The sites where intraplate volcanism of lesser net volume is concentrated were termed "hotspots", initially with no specific connotation of origin.

By recasting the observation of Chubb (1957) that linear chains of intraplate Pacific islands and seamounts commonly display a monotonic age progression, Wilson (1963) argued that each was formed as the Pacific plate drifted over a long-lived hotspot in the underlying mantle. Motion of Pacific lithosphere over deeper mantle is so rapid $(\sim 100 \mathrm{~mm} / \mathrm{yr})$ that any magma hearth active for even a few million years can generate a hotspot track hundreds of kilometers long (Dickinson, 1998).

To bring hotspot behavior under the logic of a global system, Morgan (1971) postulated that each salient hotspot is the place where a hot mantle plume, rising by columnar advection from near the core-mantle interface, reaches the surface of the Earth. Such deep-seated features ought to be almost fixed in position within the mantle, relative to the rapid motions of more surficial plates, hence potentially define a spatial framework from which to gauge "absolute" rates of plate motion.

Although the issue remains controversial (DePaolo and Manga, 2003 vs. Foulger and Natland, 2003), much of the extant petrologic and tectonic literature accepts the equivalence of mantle plumes and magmatic hotspots even though observed hotspots fail many plume predictions. Geometric analysis has shown repeatedly that all oceanic hotspots cannot be fixed relative to one another, because mutually fixed hotspots would generate hotspot tracks at azimuths incompatible with established relative plate motions (Norton, 2000). Moreover, some Pacific island-seamount chains are the products of multiple or migratory hotspots, or involve eruptions distinctly out of age-space sequence (Dickinson, 1998).

On the other hand, a range of igneous phenomena not linked directly to hotspot tracks have also been attributed to plume activity. For example, isolated hotspots distributed over wide areas have been attributed to plume magma that spreads laterally beneath the lithosphere for thousands of kilometers from a single deep-seated columnar source (Ebinger and Sleep, 1998). Voluminous but distinctly transient flood-basalt eruptions have been attributed to the effects of plume heads impinging on the surface ahead of rising plume tails (Richards and others, 1989; White and McKenzie, 1995).

Arguments that plume theory is fatally flawed (Anderson, 1998; Hamilton, 2002) have met a mixed reception by plume enthusiasts. If one is permitted conceptually to vary the shapes and sizes of plumes, to allow plume magma to travel arbitrarily long distances just beneath the lithosphere, and to vary the intensity of advection by postulating plume heads and tails of different volume and buoyancy as circumstances require, then plume theory becomes too flexible to test by observing surface geology. To date, however, seismic tomography has failed to provide robust evidence for narrow plumes at depth (Fukao, 1992; Kárason and van der Hilst, 2000).

If plumes are but another attractive geomyth, clinging to the plume concept can only serve to delay recognition of differences among hotspots, which may reflect a 
range of mantle phenomena, each potentially informative of Earth behavior but all now masked under the plume umbrella. Viewing "plume" as just shorthand for any of various kinds of anomalously hot mantle seems to me a liberating point of view. A recent analysis of the Yellowstone hotspot (Christiansen and others, 2002) indicates the complexity of the geologic processes that may give rise to igneous activity commonly ascribed to mantle plumes.

\section{GLOBAL SEQUENCES}

The notion of unconformity-bounded stratal sequences (Posamentier and Allen, 1999), inferred to be eustatically controlled and globally correlable, was developed to interpret the vast body of previously unavailable subsurface stratigraphic information generated by seismic reflection profiling of sedimentary basins. The need for a fresh means of correlation was pressing because normal methods of biostratigraphy are impractical to apply to the huge volumes of unsampled strata imaged by seismic reflection.

This analytical challenge was putatively solved by the remarkable postulate that seismic reflectors are chronostratigraphic horizons (Vail and others, 1977; Vail, 1992), constituting a graphic proxy for biostratigraphy rather than being just another format to display physical stratigraphy. This conclusion is clearly untenable in a literal sense because seismic reflection is a function of acoustic impedance, defined as seismic velocity times rock density (Sheriff, 1977). Variations in physical rock properties cannot be rigorously time-dependent.

The assumption that seismic reflectors are chronostratigraphic must rest, therefore, on trust that lateral migration of the sedimentary events or environments responsible for depositing stratigraphic layers of consistent physical character and resultant properties is rapid with respect to time frames of interest for stratigraphic correlation. Even though the generation of each reflector requires a finite interval of progradation or lateral migration of process, the requisite time interval can be short in comparison to the time frame relevant for correlation.

It seems likely, however, that strict equivalence of stacked reflector patterns with chronostratigraphy is a claim that bears close examination before full acceptance in any specific case. The conceptual problem involved is illustrated by the standard treatment of unconformities in seismic stratigraphy. Although the length of the hiatus at a given unconformity is quite properly taken to vary areally, little attention is paid in practice to the truism that a given surface of unconformity may represent, from place to place, different intervals of time that do not overlap. A salient type of timetransgressive unconformity is formed by progressive coastal ravinement as marine transgression advances on a subsiding lowland coast receiving sediment throughout the interval of shifting strandlines (Nummedal and Swift, 1987).

Adherence to the rubric that seismic stratigraphy is chronostratigrapic has led to the recognition of supposedly synchronous global stratigraphic sequences controlled by cyclic eustasy (Haq and others, 1987, 1988; Hardenbol and others, 1998), which is undetectable by independent means and for which there is no known mechanism operative at the tempo inferred. Critics have pointed out that autocyclic sedimentary processes influence local seismic stratigraphy as strongly as allocyclic processes such as eustasy (Poulsen and others, 1998), that much sequence stratigraphy reflects regional tectonism (Summerhayes, 1986; Ettensohn, 1994; Nystuen, 1998) or fluctuating sediment supply (Fulthorpe and Carter, 1989) rather than eustasy, that the stratigraphic evolution of basin margins is influenced by flexural effects from sediment loading that can mimic supposed eustatic controls (Watts and Thomas, 1984), that the spacing in time of inferred global cycles is too close to be tested by biostratigraphic data (Miall, 1992), that carefully controlled magnetostratigraphy conflicts locally with age inferences derived from global cycle charts (Prothero, 2001), and that a systematic 
reduction in the apparent average duration of global eustatic cycles through MesozoicCenozoic time is better viewed as an artifact of methodology than as a valid record of Earth behavior (Dickinson, 1993).

As criticisms of global sequence stratigraphy are largely ignored by its proponents (Miall and Miall, 2000), the literature on sequence stratigraphy has evolved along two parallel tracks, one pro and one con, with little intersection of thought. The postulate of global eustatic cycles at the "Vail scale" shares with myth the prime characteristic of using an a priori assumption, that seismic reflectors are chronostratigraphic, as the prime means for resolving issues of correlation which remain unresolved if the assumption is faulty.

\section{SUMMARY OVERVIEW}

An important concern is whether geomyths retard our thinking, or encourage research that leads to improved concepts. My prejudice is that investigations pursued under the aegis of various geomyths often embody too narrow a focus, failing to embrace a wide enough view of the phenomena in question. The seductive attraction of any myth is to eliminate conceptual uncertainty by providing comprehensive solutions for challenging puzzles, yet we learn new things only by acknowledging uncertainty and addressing paradox forthrightly.

Without rejecting the mental stimulus that geomyths afford, we could benefit from resisting any tendency to accord special status to the observations and arguments that underpin them. Why, in order to gain a sympathetic hearing, should the opponent of a geomyth have to assemble evidence against it more conclusive than the original evidence in favor of it?

The advantages of innovative induction can be preserved without lapsing into a mythic mode by reasoning with the guidance of strong inference (Platt, 1964), whereby inductive inferences are succeeded at once by deductive predictions (based on the inductive inferences) designed deliberately to test each inductive leap for potential disproof. When an inference is found wanting in any respect, it is then immediately adjusted or rejected, and the process repeated with an improved inference. If sequential tests are pursued with vigor, this approach guarantees that inductive inferences remain falsifiable, and do not grow inadvertently into untested geomyths having more durability than ultimate utility.

\section{REFERENCES}

Anderson, D. L., 1998, The scales of mantle convection: Tectonophysics, v. 284, p. 1-17.

Beck, M. E., Jr., 1991, Case for northward transport of Baja and coastal southern California: Paleomagnetic data, analysis, and alternatives: Geology, v. 19, p. 506-509.

1992, Tectonic significance of paleomagnetic results for the western conterminous United States, in Burchfiel, B. C., Lipman, P. W., and Zoback, M. L., editors, The Cordilleran orogen: conterminous U.S.: Boulder, Geological Society of America Geology of North America, v. G-3, p. 683-697.

Butler, R. F., Dickinson, W. R., and Gehrels, G. E., 1991, Paleomagnetism of coastal California and Baja California: alternatives to large-scale northward transport: Tectonics, v. 10, p. 561-576.

Butler, R. F., Gehrels, G. E., and Kodama, K. P., 2001, A moderate translation alternative to the Baja British Columbia hypothesis: GSA Today, v. 11, n. 6, p. 4-10.

Butler, R. F., Gehrels, G. E., and Baldwin, S. L., 2002, Paleomagnetism and geochronology of the Ecstall pluton in the Coast Mountains of British Columbia: Evidence for local deformation rather than large-scale transport: Journal of Geophysical Research, v. 107 (No. B1, 10.1029/2001JB000270), p. 3-1 to $3-13$.

Cady, W. M., 1950, Classification of geotectonic elements: American Geophysical Union Transactions, v. 31, p. $780-785$.

Chamberlin, T. C., 1897, The method of multiple working hypotheses: Journal of Geology, v. 5, p. 837-848.

Christiansen, R. L., Foulger, G. R., and Evans, J. R., 2002, Upper-mantle origin of the Yellowstone hotspot: Geological Society of America Bulletin, v. 114, p. 1245-1256.

Chubb, L. J., 1957, The pattern of some Pacific island chains: Geological Magazine, v. 94, p. 221-228. 
Coney, P. J., 1970, The geotectonic cycle and the new global tectonics: Geological Society of America Bulletin, v. 81, p. $739-748$.

1989, Structural aspects of suspect terranes and accretionary tectonics in western North America: Journal of Structural Geology, v. 11, p. 107-125.

Coney, P. J., Jones, D. L., and Monger, J. W. H., 1980, Cordilleran suspect terranes: Nature, v. 288, p. 329-333.

Cowan, D. S., 1994, Alternate hypotheses for the mid-Cretaceous paleogeography of the western Cordillera: GSA Today, v. 4, p. 181, 184-186.

Cowan, D. S., Brandon, M. T., and Garver, J. I., 1997, Geologic tests of hypotheses for large coastwise displacements - a critique illustrated by the Baja British Columbia controversy: American Journal of Science, v. 297, p. 117-173.

DePaolo, D. J., and Manga, M., 2003, Deep origin of hotspots - the mantle plume model: Science, v. 300, p. $920-921$.

Dewey, J. F., and Bird, J. M., 1970, Plate tectonics and geosynclines: Tectonophysics, v. 10, p. 625-638.

Dewey, J. F., and Horsfield, B., 1970, Plate tectonics, orogeny, and continental growth: Nature, v. 224, p. 1031-1035.

Dickinson, W. R., 1962, Petrogenetic significance of geosynclinal andesitic volcanism along the Pacific margin of North America: Geological Society of America, v. 73, p. 1241-1256.

1970, Relations of andesites, granites, and derivative sandstones to arc-trench tectonics: Reviews of Geophysics and Space Physics, v. 8, p. 813-860.

1971a, Plate tectonic models of geosynclines: Earth and Planetary Science Letters, v. 10, p. 167-174.

1971b, Plate tectonics in geologic history: Science, v. 174, p. 107-113.

1993, Exxon global cycle chart [Comment]: Geology, v. 21, p. 282-283.

1998, Geomorphology and geodynamics of the Cook-Austral island-seamount chain in the South Pacific Ocean: Implications for hotspots and plumes: International Geology Review, v. 40, p. 10391075.

Dickinson, W. R., and Lawton, T. F., 2001, Carboniferous to Cretaceous assembly and fragmentation of Mexico: Geological Society of America Bulletin, v. 113, p. 1142-1160.

Dietz, R. S., and Holden, J. C., 1966, Miogeoclines in space and time: Journal of Geology, v. 74, p. 566-583.

Ebinger, C. J., and Sleep, N. H., 1998, Cenozoic magmatism throughout east Africa resulting from impact of a single plume: Nature, v. 395, p. 788-791.

Ernst, W. G., 1984, Californian blueschists, subduction, and the significance of tectonostratigraphic terranes: Geology, v. 12, p. 436-440.

Ettensohn, F. R., 1994, Tectonic control on formation and cyclicity of major Appalachian unconformities and associated stratigraphic sequences, in Dennison, J. M., and Ettensohn, F. R., editors, Tectonic and eustatic controls on sedimentary cycles: SEPM (Society for Sedimentary Geology) Concepts in Sedimentology and Paleontology, v. 4, p. 217-242.

Foulger, G. R., and Natland, J. H., 2003, Is "hotspot" volcanism a consequence of plate tectonics?: Science, v. 300, p. 921-922

Fukao, Y., 1992, Seismic tomogram of the Earth's mantle: geodynamic implications: Science, v. 258, p. $625-630$.

Fulthorpe, C. S., and Carter, R. M., 1989, Test of seismic sequence methodology on a Southern Hemisphere passive margin: The Canterbury basin, New Zealand: Marine and Petroleum Geology, v. 6, p. 348-359.

Gastil, G., 1991, Is there a Oaxaca-California megashear?: Conflict between paleomagnetic data and other elements of geology: Geology, v. 19, p. 502-505.

Gilbert, G. K., 1886, The inculcation of scientific method by example, with an illustration drawn from the Quaternary of Utah: American Journal of Science, v. 31 (3rd Series), p. 284-299.

Hamilton, W. B., 1990, On terrane analysis: Royal Society of London Philosophical Transactions, v. A331, p. 511-522.

2002, The closed upper-mantle circulation of plate tectonics, in Stein, S., and Freymueller, J. T., editors, Plate boundary zones: American Geophysical Union Geodynamics Series, v. 30, p. 359-410.

Haq, B. U., Hardenbol, J., and Vail, P. R., 1987, Chronology of fluctuating sea levels since the Triassic: Science, v. 235, p. 1156-1167.

1988, Mesozoic and Cenozoic chronostratigraphy and cycles of sea-level change, in Wilgus, C. K., Hastings, B. S., Posamentier, H., Van Wagoner, J., Ross, C. A., and Kendall, C. G. St. C., editors, Sea-level changes: an integrated approach: Society of Economic Paleontologists and Mineralogists Special Publication No. 42, p. 71-108.

Hardenbol, J., Thierry, J., Farley, M. B., Jacquin, T., de Graciansky, P. C., and Vail, P. R., 1998, Mesozoic and Cenozoic sequence chronostratigraphic framework of European basins, in de Graciansky, P. C., Hardenbol, J., Jacquin, T., and Vail, P. R., editors, Mesozoic and Cenozoic sequence stratigraphy of European basins: SEPM (Society for Sedimentary Geology) Special Publication No. 60, p. 3-13 (and Chart 1).

Howell, D. G., Jones, D. L., and Schermer, E. R., 1985, Tectonostratigraphic terranes of the Circum-Pacific region, in Howell, D. G., editor, Tectonostratigraphic terranes of the Circum-Pacific region: Houston, Circum-Pacific Council for Energy and Mineral Resources Earth Science Series, v. 1, p. 3-30.

Hsü, K. J., 1973, The odyssey of geosyncline, in Ginsburg, R. N., editor, Evolving concepts in sedimentology: Baltimore, Johns Hopkins University Press, p. 66-92.

— 1982, Geosynclines in plate-tectonic settings: Sediments in mountains, in Hsü, K. J., editor, Mountain building processes: New York, Academic Press, p. 3-12

Hudson, T. L., 1987, Suspect philosophy?: Geology, v. 15, p. 1051.

Irving, E., 1979, Paleopoles and paleolatitudes of North America and speculations about displaced terrains: Canadian Journal of Earth Sciences, v. 16, p. 669-694. 
Irving, E., and Wynne, P. J., 1990, Paleomagnetic evidence bearing on the evolution of the Canadian Cordillera: Royal Society of London Philosophical Transactions, v. A331, p. 487-509.

Irving, E., Woodsworth, G. J., Wynne, P. J., and Morrison, A., 1985, Paleomagnetic evidence for displacement from the south of the Coast Plutonic Complex, British Columbia: Canadian Journal of Earth Sciences, v. 22, p. 584-598.

Irving, E., Wynne, P. J., Thorkelson, D. J., and Schiarizza, P., 1996, Large (1000 to $4000 \mathrm{~km}$ ) northward movements of tectonic domains in the northern Cordillera, 83 to 45 Ma: Journal of Geophysical Research, v. 101, p. 17,901-17,916.

Kárason, H., and van der Hilst, R. D., 2000, Constraints on mantle convection from global tomography, in Richards, M. A., Gordon, R. G., and van der Hilst, R. D., editors, The history and dynamics of global plate motions: American Geophysical Union Geophysical Monograph 121, p. 277-288.

Karl, S. M., and Mull, C. G., 1993, Appeal for nonproliferation of escalating terrane nomenclature, in Dusel-Bacon, C., and Till, A. B., editors, Geologic studies in Alaska by the U.S. Geological Survey, 1992: U.S. Geological Survey Bulletin 2068, p. 71-78.

Kay, M., 1951, North American geosynclines: Geological Society of America Memoir 48, 143 p.

Keppie, J. D., and Dallmeyer, R. D., 1991, Introduction to terrane analysis and the tectonic map of Premesozoic terranes in Circum-Atlantic Phanerozoic orogens: Departamento de Geología, Universidad de Chile, Santiago, Communicationes No. 42, p. 112-118.

Knopf, A., 1948, The geosynclinal theory: Geological Society of America Bulletin, v. 59, p. 649-670.

Mahoney, J. B., Tikoff, B., Maxson, J., and Haugerud, R., 2000, Terrane accretion along the western Cordilleran margin: Constraints on timing and displacement: GSA Today, v. 10, n. 2, p. 11-13.

Martin, R. F., and Piwinskii, A. J., 1972, Magmatism and tectonic settings: Journal of Geophysical Research, v. 77 , p. $4966-4975$.

Miall, A. D., 1992, Exxon global cycle chart: An event for every occasion?: Geology, v. 20, p. 787-790.

Miall, A. D., and Miall, C. E., 2000, Sequence stratigraphy as a scientific enterprise: The evolution and persistence of conflicting paradigms: Earth-Science Reviews, v. 54, p. 321-348.

Mitchell, A. H., and Reading, H. G., 1969, Continental margins, geosynclines, and ocean floor spreading: Journal of Geology, v. 77, p. 629-646.

Monger, J. W. H., 1993, Canadian Cordilleran tectonics: From geosynclines to crustal collage: Canadian Journal of Earth Sciences, v. 30, p. 209-231.

Monger, J. W. H., and Price, R. A., 1996, Comment on "Paleomagnetism of the Upper Cretaceous strata of Mount Tatlow: Evidence for $3000 \mathrm{~km}$ of northward displacement of the eastern Coast Belt, British Columbia" by P. J. Wynne et al., and on "Paleomagnetism of the Spences Bridge Group and northward displacement of the Intermoontane Belt, British Columbia: A second look" by E. Irving et al.: Journal of Geophysical Research, v. 101, p. 13,793-13,799.

Morgan, W. J., 1971, Convection plumes in the lower mantle: Nature, v. 230, p. 42-43.

Norton, I. O., 2000, Global hotspot reference frames and plate motions, in Richards, M. A., Gordon, R. G., and van der Hilst, R. D., editors, The history and dynamics of global plate motions: American Geophysical Union Geophysical Monograph 121, p. 339-357.

Nummedal, D., and Swift, D. J. P., 1987, Transgressive stratigraphy at sequence-bounding unconformities: some principles derived from Holocene and Cretaceous examples, in Nummedal, D., and Howard, J. D., editors, Sea-level fluctuation and coastal evolution: Society of Economic Paleontologists and Mineralogists Special Publication No. 41, p. 241-260.

Nystuen, J. P., 1998, History and development of sequence stratigraphy, in Gradstein, F. M., and Sandvik, N. J., editors, Sequence stratigraphy - concepts and applications: Norwegian Petroleum Society Special Publication No. 8, p. 31-116.

Platt, J. R., 1964, Strong inference: Science, v. 146, p. 347-353.

Popper, K. R., 1962, Conjectures and refutations; the growth of scientific knowledge: New York, Basic Books, $412 \mathrm{p}$.

Posamentier, H. W., and Allen, G. P., 1999, Siliciclastic sequence stratigraphy - concepts and applications: SEPM (Society for Sedimentary Geology) Concepts in Sedimentology and Paleontology No. 7, 210 p.

Poulsen, C. J., Flemings, P. B., Robinson, R. A. J., and Metzger, J. M., 1998, Three-dimensional stratigraphic evolution of the Miocene Baltimore Canyon region: Implications for eustatic interpretations and the systems tract model: Geological Society of America Bulletin, v. 110, p. 1105-1122.

Prothero, D. R., 2001, Magnetostratigraphic tests of sequence stratigraphic correlations from the southern California Paleogene:Journal of Sedimentary Research, v. B71, p. 526-536.

Richards, M. A., Duncan, R. A., and Courtillot, V. E., 1989, Flood basalts and hotspot tracks: Plume heads and tails: Science, v. 246, p. 103-107.

Şengör, A. M. C., 1990, Lithotectonic terranes and the plate tectonic theory of orogeny: A critique of the principles of terrane analysis, in Wiley, T. J., Howell, D. G., and Wong, F. L., editors, Terrane analysis of China and the Pacific rim: Houston, Circum-Pacific Council for Energy and Mineral Resources Earth Science Series, v. 13, p. 9-44.

Şengör, A. M. C., and Dewey, J. F., 1990, Terranology: vice or virtue?: Royal Society of London Philosophical Transactions, v. A331, p. 457-477.

Sheriff, R. E., 1977, Limitations on resolution of seismic reflections and geologic detail derivable from them, in Payton, C. E., editor, Seismic stratigraphy - applications to hydrocarbon exploration: American Association of Petroleum Geologists Memoir 26, p. 3-14.

Summerhayes, C. P., 1986, Sealevel curves based on seismic stratigraphy: Their chronostratigraphic significance: Palaeogeography, Palaeoclimatology, Palaeoecology, v. 57, p. 27-42.

Vail, P. R., 1992, The evolution of seismic stratigraphy and the global sea-level curve, in Dott, R. H., Jr., editor, Eustasy: The historical ups and downs of a major geological concept: Geological Society of America Memoir 180, p. 83-91. 
Vail, P. R., Todd, R. G., and Sangree, J. B., 1977, Seismic stratigraphy and global changes of sea level, Part 5: chronostratigraphic significance of seismic reflections, in Payton, C. E., editor, Seismic stratigraphy applications to hydrocarbon exploration: American Association of Petroleum Geologists Memoir 26, p. $99-116$.

Vandall, T. A., 1993, Cretaceous Coast Belt paleomagnetic data from the Specht Creek pluton, British Columbia: Evidence for the "tilt and moderate displacement" model: Canadian Journal of Earth Sciences, v. 30, p. 1037-1048.

Watts, A. B., and Thomas, J., 1984, Tectonics, global changes in sea level, and their relationship to stratigraphical sequences at the US Atlantic continental margin: Marine and Petroleum Geology, v. 1 , p. $319-338$.

White, R. S., and McKenzie, D., 1995, Mantle plumes and flood basalts: Journal of Geophysical Research, v. 100 , p. $17,543-17,585$

Williams, H., and Hatcher, R. D., Jr., 1982, Suspect terranes and accretionary history of the Appalachian orogen: Geology, v. 10, p. 530-536.

Wilson, J. T., 1963, A possible origin for the Hawaiian Islands: Canadian Journal of Physics, v. 41, p. 863-870.

Wyllie, P. J., 1976, The way the world works: An introduction to the new global geology and its revolutionary development: New York, Wiley, $296 \mathrm{p}$

Wynne, P. J., Thorkelson, D. J., Kleinspehn, K. L., Maxson, J. A., and Irving, E., 1996, Reply: Journal of Geophysical Research, v. 101, p. 15, 801-15,803. 